\title{
Impact of Hydrogen Bonding on the Susceptibility of Peptides to Oxidation
}

\author{
Bun Chan, * Damian Moran, Christopher J. Easton, * and Leo Radom*
}

\begin{abstract}
The tendency of peptides to be oxidized is intimately connected with their function and even their ability to exist in an oxidative environment. Here we report high-level theoretical studies that show that hydrogen bonding can alter the susceptibility of peptides to oxidation, with complexation to a hydrogen-bond acceptor facilitating oxidation, and vice versa, impacting the feasibility of a diverse range of biological processes. It can even provide an energetically viable mechanistic alternative to direct hydrogen-atom abstraction. We find that hydrogen bonding to representative reactive groups leads to a broad $\left(\sim 400 \mathrm{~kJ} \mathrm{~mol}^{-1}\right)$ spectrum of ionization energies in the case of model amide, thiol and phenol systems. While some of the oxidative processes at the extreme ends of the spectrum are energetically prohibitive, subtle environmental and solvent effects could potentially mitigate the situation, leading to a balance between hydrogen bonding and oxidative susceptibility.
\end{abstract}

Peptides are one of the main building blocks of life, and their reactivity towards oxidation is of key relevance to their function. Understanding this chemistry requires a thorough knowledge of the associated fundamental thermochemical parameters and, in recent years, accurate theoretical calculations have provided an alternative to experimental methods to obtain such data reliably, ${ }^{1,2}$ with the advantage of being able to simultaneously and directly probe the structures of the reacting species. This approach has been used, for example, in recent theoretical work on vertical ionization energies of $\alpha$-amino acids, ${ }^{3,4}$ and radical cations of amino acids and peptides, ${ }^{5}$ as well as in our own previous studies of hydrogen-atom abstraction from small amino acids and peptides. ${ }^{6}$

In this context, we have recently been using theory to investigate the oxidation of small peptide derivatives of amino acids. During the course of this study, we observed a substantial effect of hydrogen bonding on the magnitude of the ionization energies (IEs). While this qualitative change is not entirely unexpected, it is also of interest to examine its biological impact. ${ }^{7}$ Due to the ubiquity of hydrogen bonds in peptides, inter alia as a prime determinant of the three-dimensional structure of proteins, ${ }^{8}$ this phenomenon is potentially of great importance. In the current article we examine it in detail, and explore its relevance to peptide function for example in electron transport ${ }^{9,10}$ and enzyme catalysis, ${ }^{11,12}$ post-translational metabolism, ${ }^{13}$ and

[*] Dr B. Chan

Graduate School of Engineering, Nagasaki University, Nagasaki 852-8521, Japan

E-mail: bun.chan@nagasaki-u.ac.jp

Dr D. Moran, Prof. L. Radom

School of Chemistry, University of Sydney, Sydney, NSW 2006, Australia

E-mail: radom@chem.usyd.edu.au

Prof. C. J. Easton

Research School of Chemistry, Australian National University,

Canberra, ACT 2601, Australia

E-mail: Chris.Easton@anu.edu.au susceptibility and resistance ${ }^{14}$ to degradation in oxidative environments.

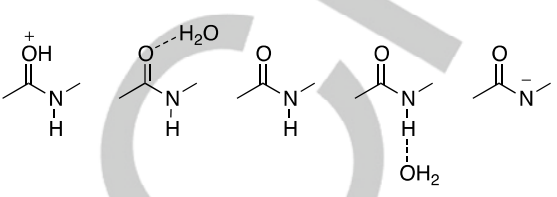

Figure 1. $N$-Methylacetamide and its variants as models for investigating the effects of protonation, deprotonation and hydrogen bonding with water, on the ionization energies of peptide backbones.

A most characteristic feature of all peptides is the amide bond. We use a small model system for this peptide backbone linkage, namely $N$-methylacetamide (Figure 1), to initially examine effects on IEs. Table 1 displays the adiabatic IEs calculated using the high-level G4(MP2)-6X procedure ${ }^{15}$ for the neutral, protonated and deprotonated forms of $\mathrm{N}$ methylacetamide, as well as for the corresponding complexes with water hydrogen-bonded at oxygen and at the amide hydrogen. To allow for the variety of peptide environments, we employ a solvent continuum model within the SMD approach ${ }^{16,17}$ to estimate environmental effects, aiming to reach broad conclusions. Energies throughout correspond to $\{\mathrm{G} 4(\mathrm{MP} 2)-6 \mathrm{X}+$ SMD[M05-2X/6-31+G(d)]\} enthalpies at $298 \mathrm{~K}$ in kJ mol${ }^{-1}$, with $1 \mathrm{eV}=96.485 \mathrm{~kJ} \mathrm{~mol}^{-1}$. Theoretical details are given in the Supporting Information.

We note that, based on comparisons with experimentally determined properties, values for generic protein dielectric constants from about 1 to over 40 have been suggested for use in implicit solvation models. ${ }^{18}$ In this respect, we believe our use of solvent parameters for octane at the one end and water at the other end covers a sufficiently wide range of environments, that distinct behaviors can be observed from the results of our calculations. Thus, the parameters for octane are used to represent a hydrophobic environment such as is created by lipids with membrane-bound proteins and within peptides by aggregation of aliphatic side chains; those for benzene are employed to model regions in the interior of proteins surrounded by aromatic groups; while those for water are used for simulation of the aqueous medium experienced by water-soluble proteins.

We see (Table 1) that, in octane, there is a large variation in the IEs, from $1220.8 \mathrm{~kJ} \mathrm{~mol}^{-1}$ for protonated $\mathrm{N}$-methylacetamide to just $352.7 \mathrm{~kJ} \mathrm{~mol}^{-1}$ for the deprotonated form, which in each case represents a change of more than $400 \mathrm{~kJ} \mathrm{~mol}^{-1}$ compared with the IE of the neutral species. Hydrogen bonding by water at the amide hydrogen of $\mathrm{N}$-methylacetamide leads to a lowering of the IE but by just $27 \mathrm{~kJ} \mathrm{~mol}^{-1}$ as a result of "partial deprotonation" and the resulting partial anionic character. In a similar manner, partial protonation by complexation of water at oxygen leads to an increase in the IE but by only $21 \mathrm{~kJ} \mathrm{~mol}^{-1}$. In higher-dielectric environments, the effects follow the same trends but are 
generally of reduced magnitude, with water leading to a greater reduction than benzene.

Intriguingly, the protonated, hydrogen-bonded and neutral forms are found to have lower IEs in water than in benzene, than in octane, while for the deprotonated form the reverse order holds. While this is consistent with expectations based on electrostatic stabilization of charged species in a higher dielectric situation, it emphasizes the important but complex impact of environment on oxidation.

Table 1. Calculated adiabatic ionization energies (G4(MP2)-6X, $\mathrm{kJ} \mathrm{mol}^{-1}$ ) for $\mathrm{N}$-methylacetamide and its variants in various condensed-phase environments

\begin{tabular}{lccc}
\hline $\begin{array}{l}\mathrm{N} \text {-Methylacetamide } \\
\text { Variant }\end{array}$ & Octane & Benzene & Water \\
\hline $\begin{array}{l}\text { Protonated at oxygen } \\
\mathrm{H} \text {-bonded by } \mathrm{H}_{2} \mathrm{O}\end{array}$ & 1220.8 & 1166.2 & 823.2 \\
$\begin{array}{l}\text { at oxygen } \\
\text { Neutral }\end{array}$ & 804.4 & 783.5 & 671.1 \\
$\begin{array}{l}\mathrm{H} \text {-bonded by } \mathrm{H}_{2} \mathrm{O} \\
\text { at amide hydrogen }\end{array}$ & 783.4 & 763.7 & 662.7 \\
\begin{tabular}{l} 
Deprotonated \\
\hline
\end{tabular} & 756.4 & 740.5 & 649.9 \\
& 352.7 & 369.5 & 500.1 \\
\hline
\end{tabular}

Let us now take a closer look at the apparent effect of hydrogen bonding to the amide hydrogen of $\mathrm{N}$-methylacetamide, to lower the IE and therefore increase the oxidative susceptibility. As noted above, the effect of water as the hydrogen-bond acceptor is calculated to be only $27 \mathrm{~kJ} \mathrm{~mol}^{-1}$ in octane and even less in the other solvents, but what are the effects of stronger hydrogen-bonding acceptors such as those that carry a negative charge? Table 2 shows IEs for $\mathrm{N}$-methylacetamide complexed with small systems used to model the deprotonated peptide side-chains of Cys $\left(\mathrm{MeS}^{-}\right)$, Tyr $\left(4-\mathrm{MeC}_{6} \mathrm{H}_{4} \mathrm{O}^{-}\right)$, and Asp and Glu $\left(\mathrm{MeCO}_{2}^{-}\right)$, and those of corresponding complexes with $\mathrm{HO}^{-}$. Optimized structures for the aqueous-phase complexes are displayed in Figure 2.

Table 2. Calculated adiabatic ionization energies (G4(MP2)-6X, $\mathrm{kJ} \mathrm{mol}^{-1}$ ) for $\mathrm{N}$-methyl-acetamide complexed with various anionic hydrogen-bond acceptors

\begin{tabular}{lccc}
\hline $\mathrm{H}$-Bond Acceptor & Octane & Benzene & Water \\
\hline $\mathrm{Nil}$ & 783.4 & 763.7 & 662.7 \\
$\mathrm{HO}^{-}$ & 385.8 & 399.3 & 515.5 \\
$\mathrm{MeS}^{-}$ & 351.1 & 364.1 & 442.5 \\
$4-\mathrm{MeC}_{6} \mathrm{H}_{4} \mathrm{O}^{-}$ & 353.4 & 365.1 & 459.5 \\
$\mathrm{MeCO}_{2}^{-}$ & 491.7 & 503.2 & 590.1 \\
\hline
\end{tabular}

At first glance it seems that complexation of the amide with $\mathrm{MeS}^{-}$and $4-\mathrm{MeC}_{6} \mathrm{H}_{4} \mathrm{O}^{-}$leads to a very large lowering of the amide IE. However, the observation that the fully-deprotonated amide has IE values (Table 1) that are as large as, or larger than, the IEs of the complexes with $\mathrm{MeS}^{-}$and 4- $\mathrm{MeC}_{6} \mathrm{H}_{4} \mathrm{O}^{-}$in Table 2 indicates a more complicated situation. Indeed, examination of Figure 2 shows that in both these cases, significant proton transfer from the amide does not accompany complexation. In addition, inspection of the molecular orbitals shows that, in each of these two cases, the low IEs correspond to the removal of an electron from the complexing anion rather than from the amide.

On the other hand, we find that interaction of $\mathrm{HO}^{-}$with the amide leads to almost full deprotonation of the amide in the complex (Figure 2), and this occurs regardless of the nature of the continuum environment. As a consequence, the resulting IEs are only slightly higher than the values in Table 1 for the fullydeprotonated amide. The complexes with $\mathrm{MeCO}_{2}{ }^{-}$represent an interesting intermediate case. Almost complete proton transfer accompanies complexation in the aqueous phase, but the geometries of the optimized complexes in the other solvents do not involve extensive deprotonation of the amide. Nevertheless, hydrogen bonding to $\mathrm{MeCO}_{2}{ }^{-}$lowers the IE of $\mathrm{N}$ methylacetamide by approximately 290 and $260 \mathrm{~kJ} \mathrm{~mol}^{-1}$, in octane and benzene, respectively (Table 2 ).
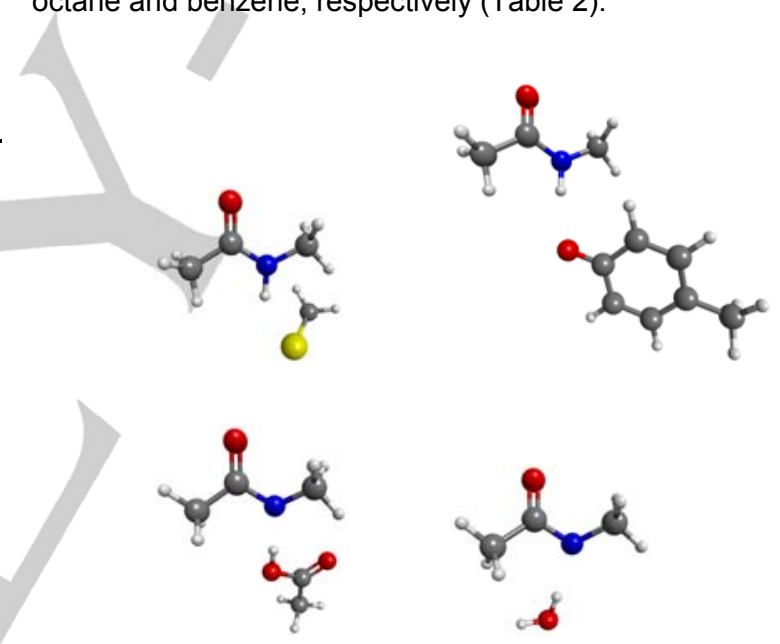

Figure 2. Optimized aqueous-phase structures for complexes between $\mathrm{N}$ methylacetamide and $\mathrm{MeS}^{-}, 4-\mathrm{MeC}_{6} \mathrm{H}_{4} \mathrm{O}^{-}, \mathrm{MeCO}_{2}{ }^{-}$and $\mathrm{HO}^{-}$.

A different biologically-related aspect that we have examined is associated with the side-chain functionalities of Cys and Tyr, which we modeled in the deprotonated forms using $\mathrm{MeS}^{-}$and 4$\mathrm{MeC}_{6} \mathrm{H}_{4} \mathrm{O}^{-}$. They are recognized as being particularly susceptible to oxidation, as exemplified through the formation of Cys disulfides in proteins, and peptide secondary metabolites through phenolic coupling, ${ }^{13}$ and reflected in the selective oxidation of these anions in the complexes with $\mathrm{N}$ methylacetamide. More broadly, thiols such as glutathione and phenols such as vitamin $\mathrm{E}$ are important antioxidants. Therefore, we now consider the impact of hydrogen bonding, protonation and environment on the IEs of these groups. Thus, in Table 3 we extend our examination of IEs of complexes of $\mathrm{MeS}^{-}$and 4$\mathrm{MeC}_{6} \mathrm{H}_{4} \mathrm{O}^{-}$in which the amide is the hydrogen-bond donor (Table 2), to include IEs of the anions and the neutral forms, 
$\mathrm{MeSH}$ and $4-\mathrm{MeC}_{6} \mathrm{H}_{4} \mathrm{OH}$, on their own, as well as in various other complexes.

Our calculations show that protonation of $\mathrm{MeS}^{-}$and 4$\mathrm{MeC}_{6} \mathrm{H}_{4} \mathrm{O}^{-}$is associated with large increases in the IEs, in accord with the general understanding of oxidations of thiols and phenols, that are thought to proceed via the corresponding anions. In octane, the increases are about 480 and $380 \mathrm{~kJ} \mathrm{~mol}^{-1}$, respectively. Although the IEs of the anions are higher in water than in benzene and octane, the IEs of $\mathrm{MeSH}$ and $4-\mathrm{MeC}_{6} \mathrm{H}_{4} \mathrm{OH}$ are lowest in water, since the magnitude of the effects of protonation is reduced to less than half in that medium. This environmental effect is analogous to that seen with $\mathrm{N}$ methylacetamide and its corresponding anion (Table 1), and can be similarly rationalized on the basis of electrostatic stabilization of charged species.

Table 3. Calculated adiabatic ionization energies (G4(MP2)-6X, $\mathrm{kJ} \mathrm{mol}^{-1}$ ) for $\mathrm{MeS}^{-}$and $4-\mathrm{MeC}_{6} \mathrm{H}_{4} \mathrm{O}^{-}, \mathrm{MeSH}$ and $4-\mathrm{MeC}_{6} \mathrm{H}_{4} \mathrm{OH}$, and their various hydrogen-bonded complexes

\begin{tabular}{|c|c|c|c|}
\hline & Octane & Benzene & Water \\
\hline $\mathrm{MeS}^{-}$ & 297.3 & 316.0 & 423.2 \\
\hline $\mathrm{MeSH}$ & 782.3 & 762.5 & 649.5 \\
\hline$\left(\mathrm{MeS}^{-}\right) \cdot(\mathrm{HOH})$ & 330.2 & 346.5 & 446.9 \\
\hline$\left(\mathrm{MeS}^{-}\right) \cdot(\mathrm{HOMe})$ & 335.4 & 349.7 & 449.4 \\
\hline$\left(\mathrm{MeS}^{-}\right) \cdot($ methylacetamide $)$ & 351.1 & 364.1 & 442.5 \\
\hline$(\mathrm{MeSH}) \cdot\left(\mathrm{HCO}_{3}{ }^{-}\right)$ & $357.3^{\mathrm{a}}$ & $371.9^{\mathrm{a}}$ & 512.7 \\
\hline 4- $\mathrm{MeC}_{6} \mathrm{H}_{4} \mathrm{O}^{-}$ & 309.1 & 324.2 & 454.5 \\
\hline 4- $\mathrm{MeC}_{6} \mathrm{H}_{4} \mathrm{OH}$ & 687.8 & 671.8 & 580.1 \\
\hline$\left(4-\mathrm{MeC}_{6} \mathrm{H}_{4} \mathrm{O}^{-}\right) \cdot(\mathrm{HOH})$ & 338.4 & 352.4 & 464.1 \\
\hline$\left(4-\mathrm{MeC}_{6} \mathrm{H}_{4} \mathrm{O}^{-}\right) \cdot(\mathrm{HOMe})$ & 343.3 & 356.8 & 465.5 \\
\hline$\left(4-\mathrm{MeC}_{6} \mathrm{H}_{4} \mathrm{O}^{-}\right) \cdot($ methylacetamide $)$ & 353.4 & 365.1 & 459.5 \\
\hline$\left(4-\mathrm{MeC}_{6} \mathrm{H}_{4} \mathrm{OH}\right) \cdot\left(\mathrm{HCO}_{3}^{-}\right)$ & 397.4 & 409.9 & 517.5 \\
\hline
\end{tabular}

aAlmost full proton transfer from $\mathrm{MeSH}$ to $\mathrm{HCO}_{3}{ }^{-}$occurs in these complexes, so the structure more closely resembles $\left(\mathrm{MeS}^{-}\right) \cdot\left(\mathrm{H}_{2} \mathrm{CO}_{3}\right)$.

By contrast to protonation, hydrogen bonding of $\mathrm{MeS}^{-}$and 4$\mathrm{MeC}_{6} \mathrm{H}_{4} \mathrm{O}^{-}$to $\mathrm{H}_{2} \mathrm{O}$, HOMe and $\mathrm{N}$-methylacetamide increases the IEs by only $30-55 \mathrm{~kJ} \mathrm{~mol}^{-1}$ in octane and benzene, and $5-25 \mathrm{~kJ}$ $\mathrm{mol}^{-1}$ in water. Thus, the susceptibility of these anionic species towards oxidation is diminished, but only slightly. In octane or benzene, complexation of MeSH with the anionic hydrogen-bond acceptor, bicarbonate, leads to almost complete proton transfer from $\mathrm{MeSH}$ to $\mathrm{HCO}_{3}^{-}$, so the complex resembles (MeS )$\cdot\left(\mathrm{H}_{2} \mathrm{CO}_{3}\right)$, and the IEs in these cases are only marginally higher than those of the other complexes of the hydrogen-bonded thiolate. With bicarbonate and $\mathrm{MeSH}$ in water, and bicarbonate and $4-\mathrm{MeC}_{6} \mathrm{H}_{4} \mathrm{OH}$ irrespective of the solvent, there is not significant proton transfer to the $\mathrm{HCO}_{3}{ }^{-}$. Even so, the IEs of the complexes are much lower than those of $\mathrm{MeSH}$ and 4$\mathrm{MeC}_{6} \mathrm{H}_{4} \mathrm{OH}$, in water by 137 and $63 \mathrm{~kJ} \mathrm{~mol}^{-1}$, respectively.
It follows from these results that the IEs of $\mathrm{MeS}^{-}$and $\mathrm{MeSH}$ provide only a very simplistic picture of the relative reactivity of these species towards oxidation. In water those values differ by more than $220 \mathrm{~kJ} \mathrm{~mol}^{-1}$ but in carbonate buffer, for example, where $\left(\mathrm{MeS}^{-}\right) \cdot\left(\mathrm{H}_{2} \mathrm{O}\right)$ and $(\mathrm{MeSH}) \cdot\left(\mathrm{HCO}_{3}^{-}\right)$might be more accurate representations of the reactants, the difference is only $66 \mathrm{~kJ} \mathrm{~mol}^{-1}$. A similar logic applies in the case of $4-\mathrm{MeC}_{6} \mathrm{H}_{4} \mathrm{O}^{-}$ and $4-\mathrm{MeC}_{6} \mathrm{H}_{4} \mathrm{OH}$. From this analysis, it becomes apparent that considerations of the antioxidant behavior of thiols and phenols under various conditions should not be restricted to the corresponding anions.

Let us now turn our attention to yet another area in which the effects of hydrogen bonds on IEs can have a biological impact. Hydrogen-atom abstraction at the $\alpha$-carbon of amino acid residues in peptides leads to backbone fragmentation that has been associated with numerous pathological disorders. ${ }^{19}$ Previously, we have studied such abstractions by $\mathrm{HO} \cdot \mathrm{HOO} \cdot$, $\mathrm{Cl} \cdot$ and $\mathrm{Br} \bullet$, and found that, although large negative reaction free energies are associated with formation of the captodativelystabilized product-peptide radicals, the calculated energy barriers favor hydrogen transfer from amino acid side chains in the cases of $\mathrm{HO} \cdot$ and $\mathrm{Cl} \cdot{ }^{6}$

The IEs of amino acid residues relative to the electron affinities (EAs) for these abstracting species allow an assessment of the susceptibility of peptides towards oxidation, as an alternative pathway for biochemical degradation. To evaluate the importance of this, we have calculated EAs for $\mathrm{HO} \cdot$, $\mathrm{HOO} \cdot \mathrm{Cl} \cdot$ and $\mathrm{Br} \cdot$ and, to extend the generality of these observations, we have also determined the corresponding values for $\mathrm{MeOO}$ - as a model of radical intermediates in peroxidations, and the nitrogen-centered radical $\cdot \mathrm{NO}_{2}$ that is prominent in air pollution ${ }^{20}$ (Table 4). Various possible reactions between the oxidants and $\mathrm{N}$-methylacetamide are illustrated in Scheme 1 for $\mathrm{HO} \cdot$, together with the corresponding reaction enthalpies.

Table 4. Calculated electron affinities (G4(MP2)-6X, kJ mol ${ }^{-1}$ ) for various oxidants

\begin{tabular}{lccc}
\hline Oxidant & Octane & Benzene & Water \\
\hline $\mathrm{HO} \cdot$ & 322.7 & 344.6 & 563.9 \\
$\mathrm{HOO} \cdot$ & 230.4 & 250.2 & 452.1 \\
$\mathrm{Cl} \cdot$ & 484.6 & 505.3 & 623.3 \\
$\mathrm{Br} \cdot$ & 447.9 & 464.4 & 558.8 \\
$\mathrm{MeOO} \cdot$ & 232.9 & 251.5 & 448.5 \\
$\cdot \mathrm{NO}_{2}$ & 339.9 & 358.6 & 516.5 \\
\hline
\end{tabular}

We can see that none of the species listed in Table 4 has the electron-accepting capability to oxidize neutral $\mathrm{N}$ methylacetamide, since the EAs of the oxidants are in all cases lower than the IE of the neutral amide, calculated in either octane, benzene or water (Table 1). For $\mathrm{HO} \cdot$ in water, this oxidation step (Scheme 1A, pathway a) is endothermic by 98.7 
$\mathrm{kJ} \mathrm{mol}{ }^{-1}$. However, the EAs of the strongest oxidants, $\mathrm{HO} \cdot, \cdot \mathrm{NO}_{2}$, $\mathrm{Cl} \cdot$ and $\mathrm{Br} \cdot$, do approach or exceed the IEs of $\mathrm{NH}$-hydrogenbonded and deprotonated $\mathrm{N}$-methylacetamide in some cases, especially in water. Under such circumstances, oxidation by these species (pathways $\mathrm{c}$ and $\mathrm{d}$ ) may therefore occur.

A)

$$
\begin{aligned}
& \mathrm{MeCO} \stackrel{+}{\mathrm{N}} \mathrm{H}-\mathrm{CH}_{3}+2 \mathrm{HO}^{-} \stackrel{(-211.4)}{\longrightarrow} \mathrm{MeCON}^{+} \mathrm{H}-\mathrm{CH}_{2}^{-}+\mathrm{H}_{2} \mathrm{O}+\mathrm{HO}^{-} \\
& \uparrow \text { pathway a (+98.7) } \\
& \mathrm{MeCONH}-\mathrm{CH}_{3}+\mathrm{HO} \cdot+\mathrm{HO}^{-} \underset{(-112.6)}{\stackrel{\text { pathway b }}{\longrightarrow}} \mathrm{MeCONH}-\mathrm{CH}_{2} \cdot+\mathrm{H}_{2} \mathrm{O}+\mathrm{HO}^{-}
\end{aligned}
$$

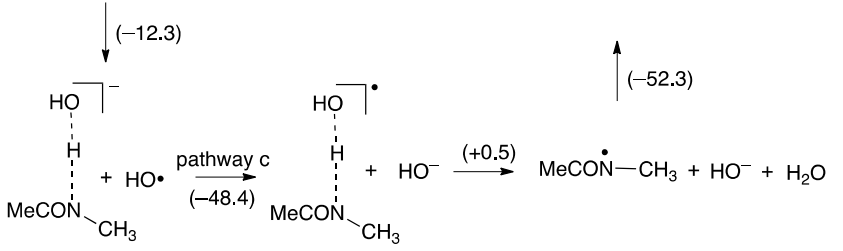

$$
\begin{aligned}
& \checkmark \text { pathway d } \mathrm{d}+15.9) \\
& \mathrm{MeCON}-\mathrm{CH}_{3}+\mathrm{HO} \cdot+\mathrm{H}_{2} \mathrm{O}
\end{aligned}
$$

B)

$\mathrm{MeCO} \dot{\mathrm{N}}-\mathrm{CH}_{3} \stackrel{-\mathrm{H}^{+}}{\longrightarrow} \mathrm{MeCON}-\mathrm{CH}_{2}{ }^{\longrightarrow} \longrightarrow \mathrm{MeCO}-\mathrm{CH}_{2} \stackrel{+}{\longrightarrow} \stackrel{+\mathrm{H}^{+}}{\longrightarrow} \mathrm{MeCONH}-\mathrm{CH}_{2} \cdot$

Scheme 1. A) Possible reactions between $\mathrm{N}$-methylacetamide and $\mathrm{HO}$ through: a) electron transfer followed by proton transfer; b) hydrogen-atom abstraction; c) complex formation through hydrogen bonding followed by electron transfer; and d) proton transfer followed by electron transfer.

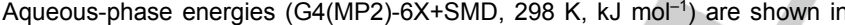
parentheses. B) Interconversion between tautomeric radicals of $N$ methylacetamide through deprotonation-reprotonation.

In the cases of $\cdot \mathrm{NO}_{2}$ and $\mathrm{Br} \cdot$, the oxidation is likely to compete with direct hydrogen-atom abstraction (pathway $b$ ) and, given the tautomeric relationship between amidyl and adjacentcarbon-centered radicals (Scheme 1B). The corresponding oxidation in peptides then constitutes an alternative, feasible pathway for $\alpha$-carbon-centered radical formation and peptidebackbone cleavage. Even though the direct hydrogen abstraction is exothermic for $\mathrm{HO} \cdot$ and $\mathrm{Cl} \cdot$, the corresponding process in peptides is kinetically disfavored, ${ }^{6}$ so oxidation by these species appears to provide a more viable route to $\alpha$ carbon-centered radicals known to be produced experimentally. ${ }^{14}$

If we now apply a similar argument to the interactions of $\mathrm{MeS}^{-}$and 4- $\mathrm{MeC}_{6} \mathrm{H}_{4} \mathrm{O}^{-}$with the various oxidants of Table 4, we can see how a balance of the IEs, as modulated by hydrogen bonding, can influence another mechanistic aspect of biological function. The EAs of the strongest of these oxidants, $\mathrm{HO} \cdot, \cdot \mathrm{NO}_{2}$, $\mathrm{Cl} \cdot$ and $\mathrm{Br} \cdot$, are larger than the IEs of both $\mathrm{MeS}^{-}$and 4$\mathrm{MeC}_{6} \mathrm{H}_{4} \mathrm{O}^{-}$, indicating that oxidation following deprotonation of $\mathrm{MeSH}$ and $4-\mathrm{MeC}_{6} \mathrm{H}_{4} \mathrm{OH}$ is a viable alternative to direct hydrogen-atom transfer, for the antioxidant activity of the thiol and phenol. The anions would be expected to be hydrogen- bonded with water in this solvent. Even then, the EAs of $\mathrm{HO}$, $\cdot \mathrm{NO}_{2}, \mathrm{Cl} \cdot$ and $\mathrm{Br} \cdot$, remain higher than the IEs of the corresponding complexes of $\mathrm{MeS}^{-}$and $4-\mathrm{MeC}_{6} \mathrm{H}_{4} \mathrm{O}^{-}$, since the hydrogen bonding diminishes the IEs by only 24 and $10 \mathrm{~kJ} \mathrm{~mol}^{-1}$, respectively (Table 3 ).

The EAs for MeOO and HOO- are too low for oxidation of either $\mathrm{MeS}^{-}$or $4-\mathrm{MeC}_{6} \mathrm{H}_{4} \mathrm{O}^{-}$, except in water where, at 448.5 and $452.1 \mathrm{~kJ} \mathrm{~mol}^{-1}$, respectively, they are similar to the IEs of 446.9 and $464.1 \mathrm{~kJ} \mathrm{~mol}^{-1}$ for the hydrogen-bonded complexes of $\mathrm{MeS}^{-}$ and $4-\mathrm{MeC}_{6} \mathrm{H}_{4} \mathrm{O}^{-}$with this solvent. This suggests a subtle solvent-dependency, whereby thiols and phenols can disrupt oxidative processes such as autoxidations and peroxidations via this mechanism in solvents such as water, but not in lipids. Conversely, the side-chain groups of Cys and Tyr may react with these types of oxygen-centered radicals when they are exposed to them in water, but be protected from such reactions in lipids or in hydrophobic domains of protein three-dimensional structures.

Finally, let us analyze the relationship between the IEs of $N$ methylacetamide, $\mathrm{MeS}^{-}$and $4-\mathrm{MeC}_{6} \mathrm{H}_{4} \mathrm{O}^{-}$, and the $\mathrm{EAs}$ of the corresponding amide radical cation, and thiyl and phenoxyl radicals. These deserve special scrutiny in the context of their relevance to peptide chemistry because, for example, thiols are understood to be involved in repairing radical damage to peptides, catalysis by some enzymes is thought to proceed via oxidative interactions between side-chain Cys and backbone Gly residues, ${ }^{8}$ and it has been suggested that amide bonds of peptides might be stepping stones for electron transfer between Tyr and Cys residues along peptide chains. ${ }^{7}$

The IE of $\mathrm{N}$-methylacetamide is so much larger than the EAs of MeS• and $4-\mathrm{MeC}_{6} \mathrm{H}_{4} \mathrm{O} \cdot$ that this simple comparison suggests that the amide radical cation would oxidize either $\mathrm{MeS}^{-}$or 4$\mathrm{MeC}_{6} \mathrm{H}_{4} \mathrm{O}^{-}$but not vice versa. However, a more-subtle picture becomes apparent from consideration of the large overlap between the ranges of IEs of $\mathrm{N}$-methylacetamide and its hydrogen-bonded and deprotonated forms $\left(352.7-783.4 \mathrm{~kJ} \mathrm{~mol}^{-}\right.$ 1 , Table 1), and those of $\mathrm{MeS}^{-}$and $4-\mathrm{MeC}_{6} \mathrm{H}_{4} \mathrm{O}^{-}$and their corresponding variants $\left(297.3-782.3 \mathrm{~kJ} \mathrm{~mol}^{-1}\right.$, Table 3$)$. This suggests that, at least in a localized environment within a biological system, a balance between oxidative susceptibility and oxidant strength is readily conceivable that would allow amide oxidation by thiyl or phenoxyl radical, the reverse, or both.

Combining the several mechanistic arguments provided above, and taking into account the relationship between amidyl and $\alpha$-carbon-centered peptide radicals (Scheme 1B), this oxidation-reduction constitutes an alternative pathway to hydrogen-atom transfer for the interconversion of thiyl radicals such as Cys• with peptide backbone radicals such as Gly•. It also allows for the possibility of electron hopping between peptide amide bonds and Cys and Tyr side chains.

In conclusion, our calculations have shown that the ionization energies and associated oxidative processes for a set of compounds related to amino acids and peptides are modified by hydrogen bonding, with complexation to a hydrogen-bond acceptor leading to more facile oxidation, and vice versa. For amides, thiols and phenols, increased hydrogen-bonding interactions, all the way through ultimately to full deprotonation, provides in each case a spectrum of oxidative susceptibilities. When the hydrogen bonding leads to a coupled oxidation- 
deprotonation reaction, the outcome is an energetically viable and sometimes preferable mechanistic alternative to direct hydrogen-atom abstraction. Overall, our results demonstrate subtle mechanisms and environmental factors that affect oxidative susceptibility, and point to important ways in which the fine balance of hydrogen bonding and oxidation is likely to impact on a broad range of oxidative processes involving peptides.

\section{Acknowledgements}

We thank the Australian Research Council (ARC) for financial support through the ARC Centre of Excellence (CE0561607) and Discovery (DP150101425) programs, and the Japan Society for the Promotion of Science through the Grant-in-Aid for Research Activity Start-up program (16H07074). The authors also gratefully acknowledge generous allocations of computing time from RIKEN ACCC, the Institute for Molecular Science, the National Computational Infrastructure $(\mathrm{NCl})$ National Facility, and Intersect Australia Ltd.

\section{Conflict of interest}

The authors declare no competing financial interests.

Keywords: amino acids • peptides • ionization energies • oxidation $\bullet$ hydrogen bonding $\bullet$ theoretical calculations

[1] For a recent review, see: A. Karton, WIRES Comput. Mol. Sci. 2016, 6, 292-310.
[2] a) H. M. Jaeger, H. F. Schaefer III, J. Demaison, A. G. Császár, W. D. Allen, J. Chem. Theory Comput 2010, 6, 3066-3078; b) M. L Stover, V. E. Jackson, M. H. Matus, M. A. Adams, C. J. Cassady, D. A. Dixon, J. Phys. Chem. B 2012, 116, 2905-2916; c) R. O. Ramabhadran, A. Sengupta, K. Raghavachari, J. Phys. Chem. A 2013, 117, 4973-4980; d) A. Karton, L. J. Yu, M. K. Kesharwani and J. M. L. Martin, Theor. Chem. Acc. 2014, 133, 1483.

[3] D.M. Close, J. Phys. Chem. A 2011, 115, 2900-2912.

[4] S. Sarkar and L. Kronik, Mol. Phys. 2016, 114, 1218-1224.

[5] A.C. Hopkinson, Mass Spec Rev 2009, 28, 655-671.

[6] a) R.J. O'Reilly, B. Chan, M.S. Taylor, S. Ivanic, G.B. Bacskay, C.J. Easton, L. Radom, J. Am. Chem. Soc. 2011, 133, 16553-16559; b) B. Chan R.J. O'Reilly, C.J. Easton, L. Radom, J. Org. Chem. 2012, 77, 9807-9812; c) R.I.J. Amos, B. Chan, C.J. Easton, L. Radom, J. Phys. Chem. B 2015,119, 783-788; d) B. Chan, C.J. Easton, L. Radom, J. Phys. Chem. A 2015, 119, 3843-3847.

[7] See also, M. Hutter and T. Clark, J. Am. Chem. Soc. 1996, 118, 75747577

[8] See, for example, K. A. Dill, Biochemistry 1990, 29, 7133-7155.

[9] C. Guo, X. Yu, S. Refaely-Abramson, L. Sepunaru, T. Bendikov, I. Pecht, L. Kronik, A. Vilan, M. Sheves, D. Cahen, PNAS 2016, 113, 1078510790

[10] a) B. Giese, S. Eckhardt, M. Lauz, in Encyclopedia of Radicals in Chemistry, Biology and Materials (Eds. C. Chatgilialoglu, A. Studer), Wiley, UK, 2012, Vol. 3, pp. 1475-1499; b) M. Cordes and B. Giese, Chem. Soc. Rev. 2009, 38, 892-901.

[11] W. Buckel, B. T. Golding, in Encyclopedia of Radicals in Chemistry, Biology and Materials (Eds. C. Chatgilialoglu, A. Studer), Wiley, UK, 2012, Vol. 3, pp. 1501-1546.

[12] a) G. M. Sandala, D. M. Smith, L. Radom, in Encyclopedia of Radicals in Chemistry, Biology and Materials (Eds. C. Chatgilialoglu, A. Studer), Wiley, UK, 2012, Vol. 3, pp. 1547-1576. b) G.M. Sandala, D.M. Smith and L. Radom, Acc. Chem. Res., 2010 43, 642-651.

[13] T. J. Osberger, D. C. Rogness, J. T. Kohrt, A. F. Stepan, C. M. White, Nature 2016, 537, 214-219.

[14] Z. I. Watts, C. J. Easton, J. Am. Chem. Soc. 2009, 131, 11323-11325.

[15] B. Chan, J. Deng, L. Radom, J. Chem. Theory Comput. 2011, 7, 112120

[16] A. V. Marenich, C. J. Cramer, D. G. Truhlar, J. Phys. Chem. B 2009 113, 6378-6396.

[17] J. Ho and M. Z. Ertem, J. Phys. Chem. A 2016, 120, 1319-1329.

[18] C. N. Schutz and A. Warshel, Proteins: Structure, Function and Genetics 2001, 44, 400-417.

[19] M. J. Davies, Biochem. J. 2016, 473, 805-825.

[20] L. F. Gamon and U. Wille, Acc. Chem. Res. 2016, 49, 2136-2145. 


\section{Entry for the Table of Contents}

\section{COMMUNICATION}

\section{lonization energy spectrum:} increased hydrogen bonding, through to full deprotonation, results in a spectrum of ionization energies for key functional groups, leading to subtle mechanisms and environmental factors that are likely to provide a fine balance between hydrogen bonding and oxidation, which impacts on a broad range of oxidative processes involving peptides.

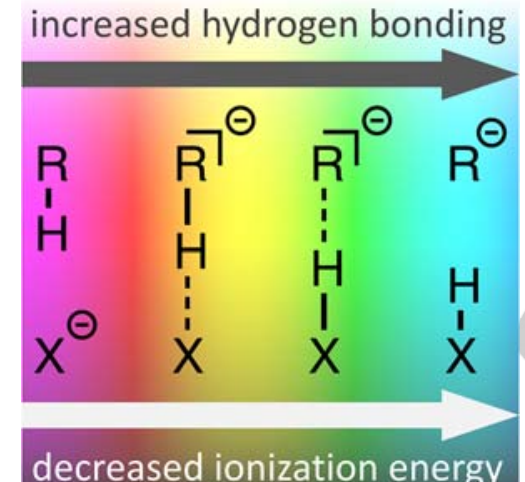

B. Chan, ${ }^{\star}$ D. Moran, C. J. Easton, ${ }^{\star} L$. Radom*

Page No. - Page No.

Impact of Hydrogen Bonding on the Susceptibility of Peptides to Oxidation 